\title{
Women and Peace Buflding Process in Global South Gountries the Importance and Limitation of the Role
}

\section{Dr. Seham Fawzi}

Faculty of Economics and Political Science Future University 


\section{Abstract}

The objective of this paper is to analyze the role of women in the peace building process in Global South countries and pinpoint the gaps and limitations of women's role within such a process. Research methods include country case study analysis based on an in-depth literature review analysis. Findings suggest recognizing the obstacles that cause such bottlenecks in women inclusion and the need for a collaborative framework to build effective women participation in order to reach a sustainable peace building process. Suggested Policies are built, enhanced, and tailored to fit into the needs of women empowerment.

Key words: women, sustainable peace building, third world, conflict resolution

\section{טمि}

تعد عملية بناء السلام من العمليات الهامة التي تضمن استقرار الدول التي عانت لفترات طويلة من الحروب، ولكن هذه العملية لكي تتجح فلابد من مشاركة جميع فئات المجتمع فيها، وعلى لهي رأس هذه الفئات المرأة، والتي تعاني عادة دول العالم الثالث من التهميش والإقصاء من المشاركة السياسية، وبالتالي من المساهمة في عملية بناء السلام وإنهاء العنف الذي تعاني منه هذه المجتمعات. وعلى الرغم من أهمية الدور التي تلعبه المرأة واهيته إلا أن هناك العديد من العوامل السياسية

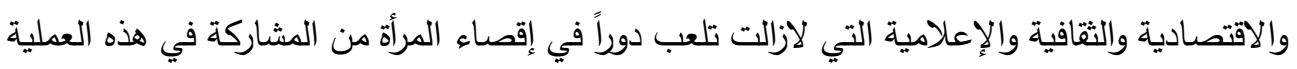
والتي تحتاج إلى حلول عاجلة حتى تضمن المجتمعات تحقيق السلام الدائم. وهذه الحلول هي حلول سياسية تتمثل في التشريعات وتخصيص نسب لمشاركة المرأة في عملية السلام، خاصة في المناصب القيادية، كما تتضمن حلولاً اقتصادية وزيادة الموارد المالية، وبالتالي تمكين المرأة من المشاركة الفعالة. كما تتطلب هذه الحلول أن تقوم وسائل الإعلام بدوراً هاما في عملية تغيير النظرة المجتمعية الرافضة

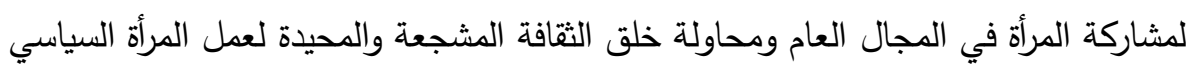
الكلمات الرئيسية: المرأة - بناء السلام - المرأة وبناء السلام بدول العالم الثالث 


\section{Introduction}

The International society has tried hard to include women in political process in their society especially after the end of civil wars and violent conflict. The United Nations for example have set" a range of measures targeted to reduce the risk of lapsing or relapsing into conflict by strengthening national capacities at all levels of conflict management and to lay the foundations for sustainable peace and development" (United Nations 2021). In fact, for many years, the international society attempted to mediate the impact of conflict on women and to include them in such a process. Resolutions 1325 and 1889 of the Security Council links between the international society and the importance of including women in both the formal peace process which includes the activities and negotiations taken by the participant in the conflict, world government and the international organizations, and the informal peace process which includes all peace activities that have taken place outside the formal negotiation process (Mason, 2009).

The first attempt that tried to include women in peace building process was Resolution 1324 of the Security Council which stressed on the importance of social inclusion of women in the formal peace process through three pillars. Pillar One highlights the importance of women's participation in all the phases and levels of decision making to build a sustainable peace process and increase participation. Pillar Two necessitates the inclusion of women as representatives and decision makers across all institutions. Pillar Three offers' mechanisms and indicators for conflict resolutions in terms of protecting women's political, economic, and social rights specifically during conflict (Ackhurst, 2014). The second attempt was Resolution 1889 of the Security Council which reemphasized the necessity of the equal representation of 
women in the informal peace building process because of the importance of their role ("Global Study on the Implementation of United Nations Security Council Resolution 1325 | UN Women", 2021).

The problem that this research is trying to explain and find solution for it is that there is a gap between the women percentage in the population and her role in peace building process. This paper is trying to find answer for the following questions:

1- Why women participation in peace building process is important?

2- What are the obstacles that hinder the participation of women in peace building process?

The objective of this paper is to highlight the importance of women participation in peace building process, the constraints that hinder the effective participation of women in the peace building activities in Global South countries and to suggest policy recommendations for effective participation of women in peace building process in Global South countries.

\section{Research Methods}

Research methods are based on role theory assumptions because they will help in identifying the role of women in peace building process and the main obstacles that hinder this role. This study will use the case study approach which will help in studying the situation of women and their involvement in the peace building process in Global South.

\section{Literature review}

There are many studies that tried to illustrate the situation of women in Global south and their role in the economic and political sphere. These studies could be classified according to this research to two main categories 
Women and Peace Building Process in Global South Countries the Importance and Limitation of the Role

\section{1- Studies that tried to mention the importance of women role in peace building process.}

There is a lot of studies that tried to explain the importance of Women participation in peace building process such as:

A-R S. Klein, The Role of Women in Mediation and Conflict Resolution: Lessons for UN Security Council Resolution 1325

In this study the author explained the importance of including women in conflict resolution activities and draw better understanding of the implication of UN Security Council Resolution 1325. The author tried to illustrate how women can play a role in negotiation and mediation and how have women differed in their approach to mediating conflict.

B- P.C. Diaz, \& S Tordjman. (2021). Women's Participation in Peace Negotiations: Connections between Presence and Influence.

This study tried to explain through giving examples how important is to include women in peace building process. The authors tried to give examples to the successful role women played in reaching peace agreements such as in Zimbabwe, Congo, and Nepal.

\section{2- Studies that tried to identify the obstacles that hinder this role.}

A- F Bari. (2005). Women's Political Participation: Issues and Challenge This study tried to identify the internal and external factors that led to the exclusion of women from the formal political arena. The study also tried to find solution for the exclusion of women from politics.

B- S Walby, Theorizing Patriarchy

This study tried to answer the following question: why are women more disadvantaged than men? The author tried to examine the effect of patriarchal culture on women chances to be included in politics. 
In my paper am trying to explore the importance of women role in building peace, the main obstacles that hinder this role and I will try to suggest solution to how to overcome these obstecles

\section{The Importance of Women Role in Peace Building Process}

Women participation in building peace is very important in Global South societies for many reasons. Women usually are the direct victims of the violence so their participant is very important, in the following section I will explain why women role is very important in peace building process.

\section{Women are direct victims of conflict}

Previous studies have emphasized the relationship between building sustainable peace to end violent conflict within Global South societies and the effective role of women in terms of participation (Klein, 2012) emphasized that although women are less likely to become part of the fighting groups in their societies during civil wars, they are usually considered the direct victims of these conflicts. Women-prone conflicts are mainly centered around sexual violence, which is a tactic used by the fighting groups to humiliate their enemies. For instance, Yezidis Women in Northern Iraq were the victims of sexual violence; they were sold as slaves, raped, and forced to change their religion. In Sierra Leone, $49 \%$ of the displaced women during the civil war were victims of sexual violence and in Rwanda 1994 civil war between 250,000 and 500,000 women were raped (Klein, 2012). Sexual violence is not the only threats to women, there are different kind of threats such as injury, death, loss of their family members, displacement, the deprivation of health care, education and employment which increase the suffering of women. One of the reasons of the suffering of women in their societies during conflict is the lose of their economic resources and the scarcity in resources which may lead 
women to work in unethical works such as adultery. The effect of the extremist group in increasing violence against women and the violation of their right is another threat that face women in these societies.

\section{Women exclusion in terms of Gender Equality}

Women are excluded from the societal participation and the participation to achieve peace in their societies. Despite the United Nations millennium goals to achieve gender equality and women empowerment (United Nations Organization), women in most of world countries make up 50\% or more from the population but they are less represented politically and economically in their societies especially in Third world countries ${ }^{(F o x, ~ 2004)}$. There are few numbers of women who participated in all the phases of conflict resolution

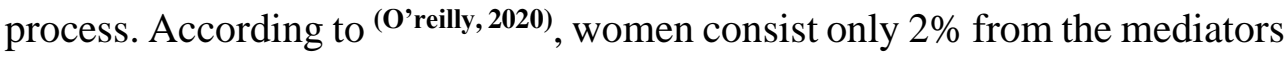
and $9 \%$ from the negotiators in peace building process during the period from 1992 to 2011. In Bosnia, for instance, women were deprived from the participation in Dayton negations and only one woman participated in Kosovo negotiations in $1999^{\text {(Porter, 2008) }}$. A study undertaken in 2008 found that in 33 peace negotiations only $4 \%$ of the negotiators were women (Democratic Progress Institutions 2014)

Gender equality and participation of women is not important only because the percentage of women to the population in their societies bur also because some scholars believe that the gender inequality may lead to internal conflict, or it may hinder the conflict resolution. In their opinion that the values of tolerance, respect and equality are very Important to achieve peace that's why the gender equality in their opinion will lead to the spread of these values in the societies that suffer from conflict (Capriole, 2005). 


\section{Recognizing the Increasing Chances of Reaching Agreements: Through Woman Engagement}

Women are more capable than men in dealing with conflicts because fighting groups do not suspect the intention of women who are engaged in resolving the conflict and they have the ability to facilitate the difficulties that face the negotiation process because Women are more capable than men in Building coalition between the diverse groups (Dwyer, et al 2012). They can work across the fighting groups to build co-operation between the women who belongs to these different ethnic and religious groups. Liberia is a good example for the importance of the role of women in building alliance across the different ethnic groups, in 2002 Muslim and Christian women organizations together pressured fighting parties into negotiations that ended the civil war there ${ }^{\text {(Lonsway, 2002) }}$. A study of 40 peace processes in 35 countries between 1989 and 2014 showed that when women are engaged in peace process it was easier to reach an agreement than in the negotiation that does not include women. Anther studies showed that when women participate effectively in the negotiation process there is high possibility that the peace agreements will last for at least two years (Barsa, 2015). In Sri Lanka, for example, when talks were foundering and leaders of the Liberation Tigers of Tamil Elam refused the negotiation with the government, the activist Visaka Dharmadasa the founder of Parents of Servicemen Missing in Action and the Association of War-Affected Women was chosen to be a messenger between the Tamil and the government (Zelizer, 2013).

Women are usually more capable than men in using non -violent methods to solve the internal conflict and there are countless examples of women who are active in civil society and in adopting effective nonviolent methods based on building cooperation and trust among the fighting groups .For example Mossarat Qadeem from Pakistan is a good example of the 
success women can achieve in radicalizing extremists through the cooperation with the legislature and the religious leaders and speaking to young males in schools and spreading awareness between them about the liars of the extremist group, also through her civil society organization PAIMAN Alumni Trust she trained almost 1000 mother and made them able to radicalized 1,024 young men and helping them to reintegrated into society (Dwyer, et al 2012)

The ability of women in solving conflicts increases on the community levels, for example in Mindanao one of Philippine's region Women are known for their role in mediation, negotiation and solving the community level dispute between the government and the Islamist movement (Barsa, 2015). Another reason that makes women more capable in dealing with conflict is that women are more patient than men in dealing with the sophisticated issues included in the internal conflict. Usually, women are mothers who are responsible than men in raising their kids and growing them on principles of peace and acceptance the others and solving the conflict on peaceful methods (York, 1998).

Women are not only capable than men in reaching peace agreements, but they are also more capable in lessening further conflicts because they play many roles during the participating in conflict such as monitoring the cease of the fire, facilitating human aid activities, mediation activities (O'reilly, 2020), and addressing issues that had been neglected from the male negotiators. All these activities will lessen the intensity of conflicts and increase the possibility of peace and this what had happened in Sudan when women delegates to Darfur Peace Agreement pushed for achieving peace and addressing the issues that had been neglected before such as displaced persons, refugees, food security and gender-based violence (Page et al, 2019). Researchers continue to emphasize the strong correlation between women 
political participation and the reduction in the possibility of conflict eruption. These studies showed that the increase in women representation in national parliament will reduce the possibility of civil war. A study of 58 conflict between 1980 and 2003 proofed that the percentage of women parliamentary increase the possibility of ending the civil wars will increase too (Jacqueline H.R et al 2014).

\section{Increasing the legitimacy of the political system}

In many cases peace building process entails re-building the political systems and to change the social and political environment which increase the opportunity to increase the participation of the marginalize segments of the society. These changes may give women the chance to benefits from these changes to increase her role in building their societies after conflicts.

Including women on the process of peacebuilding will give women the chance to include the topics of women right and gender equality to the negotiation process agenda and this may improve women situation in their societies and increase the stability and legitimacy of the newly borne system because all the member of the society will be included in decision making process. The political system that will emerge after conflict resolution will affect women's life and the absence of women from participating in this process will lead to the absence of women's concerns from the new political system arrangements. Adding these issues to the process of building the peace and new political system will mean that women will be represented in this process, and this will increase the legitimacy of the newly born political system. In Burundi women succeeded in forcing the newly political systems to give women a $30 \%$ gender quota. (Domingo, et al 2013).

Women participation increases the possibility of achieving transparency during all the phases of conflict resolution process. Women usually prefer to inform the society about the results of negotiation. For 
example, women in Burundi used to inform the society about the result of the negotiations process and this increased the support of women participation there (Promoting Women's Participation in Peace Negotiations and Peace Processes, 2014).

From the previous section we can say that women role is important in peacebuilding process because they are the direct victims of the conflict, and their exclusion will increase gender inequality. It's very important in my opinion to increase women participation in conflict resolution process because their participation will increase the possibility of reaching agreement and it will increase the legitimacy of the political system.

\section{Obstacles to women participation in peace building process}

Although the Security Council Resolution 1325 attempted to improve the percentage of women in peace building process by urging the government all over the world to take all the needed measures to implement the resolution to include it in their national legislation, only partial and slow progress had been achieved regarding women participation in peace talks. Women participation depends on the country social and political environment. Rwanda for example declared in its constitution of 2003 a commitment to grant Rwandan women at least $30 \%$ of posts in decision -making organization. The government consequently trained women to be part of police forces to deal with the sexual abuse and to prevent it in future (Democratic Progress Institute website). On contrary, women in Iraq were denied the right to participate in any activities to end the sectarian violence there. Many factors usually hinder women inclusion in peace building activities, the following part of the paper will explain such factors. 


\section{Cultural factors}

Most of Third World countries could be described as societies with Patriarchal cultural which put women in statues lower than men. Patriarchal means the domination of the father over the member of the family and the family member will subordinate to the father. As a system patriarchy means "a system of social structures and practices in which men dominate, oppress and exploit women (Welby, 1997). The patriarchal cultures include women subordination which means the humble situation of women and their limited access to economic and political resources. In other words, it entails the women powerlessness and discrimination against them.

Women subordination means that men dominate women because they view women different than men, and this make them always dependent on men (Sultana, 2012). Patriarchal culture and women subordination limited women self-esteem and self-confidence which limited their role in their societies. Usually, the Patriarchal culture reduce the women statues and treat them as if they were in lower than men.

Patriarch system include different types of subordination which were used to keep women away the power systems. According to this system, there are two distinct forms of private and public patriarchy. The private one consolidates the traditional role of women and based on household issues and women will suffer in this type from discrimination, insult, violence, disregard, control, exploitation, and oppression. Women subordination according to the privet patriarchal will include family preference to educate boys over girls, allocating more food to boys more than girls, sometimes this culture prohibited women from inheritance, and violence against women. Public patriarchy is dealing with women in work, society and politics and this culture is playing important role in the limitation of women role in their society. Men 
usually consider the public sphere is only for them and women should keep out of this sphere, and this confirm that the norms and practices that control and define the role of women in the privet sphere will control and define the role of women in the public sphere, as a result all the power within both spheres will remain under men control and women will be deprived from their rights to be engaged in their societies (Ibid, $\mathbf{p}$ 60).

The patriarchal culture plays important role in preventing women in participating in the peace building process. One of the obstacles that this culture create is the difficulty to balance between women duties towards her family and her effective engagement in the peace process activities. Women in the traditional society is responsible for running their houses and raising their kids because according to the norms of values of the patriarchal culture the only accepted role of women is to be mothers and wives which leave little time for women to participate in politics or in peace building process (Bari, 2005). The patriarchal culture is the main obstacle to women political participation and its role during the conflicts. Usually, their family will refuse their participation in the activities to end the conflict because include a high degree of insecurity and the risk that women could be victims of the violence.

Women subordination will affect women by depriving them from the experience they needed to be able to participate in the activities that aim to end violence especially in decision making and leadership position. Women in traditional societies are usually marginalized also lack the societal support and the acceptance to their efforts and participation in the peace building activities. The patriarchal system of leadership still refuses to accept women as a leader and will face the idea with hostility women still faced a lot of hostility when it came to leadership. The marginalization of women in political leadership and their continued exclusion from decision making 
positions made lots of women not confident about their abilities and prevent them from participation in any political activities (Potter, 2008).

\section{Political and legislative factors:}

Even though women inclusion is supported in many of the world constitutions, but few countries tried to take action to translate these articles to action. In most of these constitutions the inclusion of women is only general articles without specification for the percentage of fields of inclusion. It is very difficult to change women situation without the governmental incentives to start the change which in my opinion will not be easy task because of the cultural limits especially in developing countries but still the governmental initiatives are first step towards the change. In another words one of the obstacles that hinder women political participation is the ability of officials to design inclusive frame work to engage women in peace building processes as negotiators, advisors, consultants and observers within formal delegations, this frame work should encourage the influential participation of women and achieve the equal and factual participation because lots of peace negotiation witnessed artificial participation, women in this negotiation will follow the policies and agenda of the groups and parties they participated through. On Third world countries if women want to participate in politics and on peace building process they should do that through political parties and usually political parties prefers men over women in their activities because they believe that the men more capable than women .They also doesn't prefer to choose women over men because of the cultural constraints that believes the physical and mental superiorities of men over women .Many women didn't have the chance to participate in peace negotiation unless they participate through political parties like for example in Somali were excluded from the official peace negotiations in 2002 regardless there activities 
informally in promoting peace in their countries. As result women formed the six clan's alliance that succeed to cross the Somalian division and they participated after that in Somali Peace and Reconciliation Conference in Djibouti (Karuru, 2001) One of the reasons that created the exclusion of women is their lack of experience in participating in peace building process which make the political parties exclude women for the participation of men.

During conflicts the national and international actors concentrate in ending the conflict and this usually mean sacrificing other issues like women's rights and gender discrimination. Although it's very important to address women right issues and equal citizenship during the negotiations to establish the new political system to increase the legitimacy of the new system but usually the negotiations lack the attention to the role and rights of women. These negotiations do not offer any plans to improve women situation or to promote women's empowerment and equality in post conflict societies (Bell, C. et al 2012). One of the obstacles that hinder women political participation in the Third World countries is the ability of officials to design inclusive framework to engage women in peace building processes as negotiators, advisors, consultants and observers within formal delegations, this framework should encourage the influential participation of women and achieve the equal participation. The political and legislative support in post conflict societies is one of the most important steps to increase women empowerment and gender inequality through institutionalizing the required methods to achieve the women inclusion in politics and in activities of ending the conflicts and achieving peace ${ }^{\text {(Bell, } \text { C. et al 2012). }}$

\section{Economic factors}

Economic inequality and limited access to economic resources hindering women political participation in general and their participation in 
peace building activities in particular. According Beijing Declaration of 1996, women are partner in producing food and they are participating in all the economic activities in their societies but still they are excluded from economic leadership positions and to be part of the economic decisionmaking process (Porter, 2008).

In most of Third World countries women are deprived from the equal accessing to the economic resources such credit and land; limited coownership of small and medium enterprises and low access to technology. Women percentage of the working force all over the world is increasing but still this didn't change their situation or ended the economic discrimination against them. Women still suffering from the marginalization in the economic sphere and the lack of training and education opportunity which keep them deprived from the economic empowerment.

Women in Third World countries according to the lack of economic empowerment suffer from poverty which limited their choices. For example, during the preliminary elections in many of the independent countries' election became a chance that will help women to get money to feed their children. They will vote for who will pay them more (Diaz, et al. 2021).

The patriarchal culture that dominates Third World societies play important role in creating the economic discriminations. This culture made property in most cases belongs to women who will be denied this right. Women also because of this culture will be assigned to specific jobs such as teaching or working in public sector with low wages (Diaz, et al. 2021). Many women are less economically secure than men as a result of many factors such as low rates of education and working in the informal sector, in Egypt for instance $46 \%$ of all working women in Egypt have vulnerable or informal jobs, compared with $21.3 \%$ of men. In addition, women who are working in this sector are paid less than men who are working in similar jobs in this sector 
(O'reilly, 2020). Moreover, women in developing countries are different than men in their attitudes towards entrepreneurship. Most of women do not have the courage or the trust in their capabilities, they fear the failure in this field which keep them away from entering the business world. Poverty and unemployment in Third World countries increased women dependency on men and hinder their political participation.

Lack of economic security is one of the reasons that hinder women participation in peace building process in their countries. For example, in northern Uganda women participated in rebuilding their societies after war but they couldn't increase their participation according to their poverty and their dependence on men to fulfil their and their kid's needs. This poor participation led to the marginalization of women and their concerns like sexual violence and the absence of promoting economic equality plans (https://www.europarl.europa.eu/portal/en).

Economic inequality and the disadvantaged socio-economic circumstances affected women ability to participate in peace building process. With limited access to economic resources, financial constraints, lesser earning to men and division of labor on sex classification women don't find time or effort to participate in politics or in conflict resolution. The economic inequality affects women participation negatively and prevent them from reaching leadership positions in peace activities and it will keep them marginalized without any real participation in building their societies after conflict and this will lead to more exclusion for women in the newly born political system (38)

\section{Media}

Mass media play an important role in shaping women political future. It used to treat women in a different manner than men. Women politician in 
everywhere are more prone to criticize than men. Criticism includes their behavior, look, and how they dress, and they are rarely their political behavior (O'Reilly et al, 2015), it also as a socialization institution reinforce the traditional of the patriarchal culture and its principles and that's why the 'masculine model' of political life prevail in the media which hinder women political participation. Media institutions usually tend to prefer covering men politician than women and neglecting the successful models of women politician.

Women in Third World countries exclusion and limited access entails the exclusion and the limited access to media which limited their opportunity to play important roles in politics and in conflict resolution activities ( $\mathbf{O}$ 'reilly et al, 2015).

Mass media usually reinforce the traditional image of women and how the society see women and their ability in politics. Talk shows and newspapers usually reinforce the traditional role of women as mothers and wives, the media concentrate on specific topics such as cooking, beauty, dieting, raising children, and home care. When the mass media deal with politics they do that as if it is muscular domain that does not include women, which play important role in limiting women political opportunity. The insisting on the traditional role of women didn't only limit its political chances but also it increased the mistrust of women ability in politics, increase their lack of confidence in their selves and it strengthen the patriarchal forces which push women to abandon politics and the leadership positions. The lack of the ability to use the new media is another problem face women in dealing with media. Women till now are not able to use this tool to change the negative impact of the traditional media in their role. Women till now not active in using new media maybe because the contradiction between the importance of being open, honest, and direct with online communication and 
Women and Peace Building Process in Global South Countries the Importance and Limitation of the Role

the need to address specific issues and send particular public massages (Zelizer, 2013)

Although women participation is important but there is a lot of factors that hinder women participation and lead to women exclusion from playing important role in conflict resolution.

\section{A Solution-Based Framework for Effective Women Participation}

This paper is offering a suggested solution-based policy framework for effective women participation to be considered. The first step is to build a legislative and institutionalized framework that will increase the appointment of women as decision makers, and as chief mediators in conflict resolution process and to expand their roles in mediating the conflict through the civil society activities. Affirmative action, policies, gender quotas and designing national agenda are effective methods to increase women inclusion in all the phases of ending conflict especially in leadership positions. In many countries the constitutions, policies, and regulation increased women participation. For instance, the Colombian constitution protected the woman rights and as a result the Colombian government adopt policies that made the state responsible to protect women rights during the armed conflicts and guarantee their participation in achieving peace (Welby, 1997). The following step is for countries to build institutions that encourage women participation in peace building providing them with the needed training to compensate their lack of experience and to enhance the quality of their contribution. These institutions should be able to provide women with financial and technical support to be able to participate in conflict resolution process in their societies. 
The third step focuses on the importance of governmental efforts to encourage women participation in peace activities and to eliminate the traditional and negative images of women and their role which shape the public opinion and cultural values and norms regarding women participation in peace activities. The governmental effort is an effective method to change the public attitude towards women participation and increase the societal confidence in them. Governments should give using media to change the traditional view regarding women priorities because media is one of the methods of socialization and it has quicker effect in changing this view towards women, also governments should use media to educate women, increase their political knowledge and encourage their participation in politics and in peace building process. Through media government can build the societal trust in women capabilities and reduce the societal refusal to women participation in the public sphere.

The fourth step is women economic empowerment is an effective method to end gender discrimination in many countries and increase the participation of women in public sphere. Economic insecurity, poverty, discrimination, and exploitation all hinder women participation in peace building activities. Women need to be included in Economic decision-making posts and encouraged to access the entrepreneur world through increase their access to comprehensive and equitable financial services such as loans, credit, saving and economic insecurity. Government financial policies which will support women financially will increase their participation in politics (Women's Economic Empowerment is a Pre-requisite for Inclusive and Equitable Economic Growth).

The role of multilateralism and collaboration is important in enhancing the role of women in the peace building process. United Nations and the international organizations are as important as of the solution through the refusal to be sponsors of any peace agreements that excludes women in the 
decision -making posts in all the phases of the resolution of the conflict. Civil societies organizations and grassroots should be encouraged to address women's economic problem and to reach marginalized women in rural areas, poor women and low -educated women and help them to find access to economic resources in their societies to improve their economic statues which will give them time to participate in politics (UN Women's Work on Economic Empowerment-Policy Brief).

\section{Conclusions and Policy Recommendations}

Since the adoption of the Security Council Resolution 1325 on 31 October 2000 , the inclusion of women in the peace building process did not achieve real progress. To this day women in Third World countries are absent from the factual participation in this process. The absence of the role of women despite its importance could be due to the result of many factors. The following steps are suggestions for effective women participation in the peace building process. Governments could increase women political participation through the following policies:

- Economic Growth Promoting Policies to create more jobs with betterpaying schemes and this will increase women opportunity to access politics and participate effectively in achieving peace in their societies.

- Public Services and Infrastructure Policies to improve basic utilities services in order to reduce the time and efforts exerted by women in daily household works which will give women more time and efforts to be engaged in political activities.

- Technology Utilization Policies to enhance the capabilities of women, to have access to information and to have various sources of education and knowledge. It also helps in changing the traditional view which 
dominate Third World societies and prevent women from working in specific jobs or participate in political activities (Urban Institute website).

- Women Empowerment Policies to encourage woman empowerment and their participation in politics through enacting laws and policies that provide childcare, change the laws that limit women's economic independence such as inheritance laws which in some countries prevent women from their rights and to enact laws that reduce men power over women's economic activity. Governments also should find a way that reduce women working in the informal sectors (European Parliament) and to provide training to women to enhance their capabilities and to help them to find jobs with better- paying.

- New Media Policies to give women chance to participate in politics and to be engaged in discussions and forming the public opinions in some issues related to women rights. It can generate an access to politics that women can use it to show their abilities in political sphere. They may create public support for the inclusion and engagement of women in politics and in peace building activities. New media may help women to overcome the obstacles of traditional cultures that prevent women from communicating directly with the masses and spending a long time outside their homes. It may offer women with opportunity to build their own social capital and to introduce themselves to their societies which will help in convincing these societies with the importance of women role in peace building (European Parliament). 


\section{References}

1. Ackhurst, M. (2014, November). A Study into the Ways to Better Incorporate Women into Peace Building and Conflict Resolution Through the Implementation of UNSCR 1325. Retrieved from https://www.academia.edu/24264972/A_Study_into_the_Ways_to_Bette r_Incorporate_Women_into_Peacebuilding_and_Conflict_Resolution_Th rough the_Implementation_of_UNSCR_1325. (Last access: 12/5/2021).

2. Bari, F. (2005). Women's Political Participation: Issues and Challenges. Bangkok: United Nations. Retrieved from: https://www.un.org/womenwatch/daw/egm/enablingenvironment2005/docs/EGM-WPD-EE-2005EP.12\%20\%20draft\%20F.pdf (Last access 24/5/2021).

3. Barsa, M.(2015, March 18). US Approaches to Countering Violent Extremism Must Prioritize Women. The Institute for Inclusive Security. Retrieved from:

http://www.inclusivesecurity.org/usapproaches-to-countering-violentextremism-must-prioritizewomen ( Last access in 10/4/2021).

4. Bell, C. \& O' Rourke, C. (2012). Peace Agreements or Pieces of Paper? The Impact of UNSC Resolution 1325 on Peace Processes and their Agreements. International and Comparative Law Quarterly, 59 volume 4, pp 941- 980.

5. Capriole, M. (2005). Primed for Violence: The Role of Gender Inequality in Predicting Internal Conflict. International Studies Quarterly, 49, No2 pp 161-178.

6. Democratic Progress Institutions (2014, Nov). A Study into the Ways to Better Incorporate Women into Peace Building and Conflict Resolution Through the Implementation of UNSCR 1325. Democratic Progress Institutions: London p 24 . Retrieved from:

https://dpidemo.webold.co/wp-content/uploads/2020/09/1325-paper-25nov-20141.pdf.(last access 12/5/2021).

7. Democratic Progress Institute. Retrieved from: https://www.democraticprogress.org/.

8. Diaz, P.C. \& Tordjman, S. (2021). Women's Participation in Peace Negotiations: Connections between Presence and Influence. Retrieved from:

http://peaceoperationsreview.org/wpcontent/uploads/2015/11/womens_p artcipation_peace.pdf (last access 23/5/2021).

9. Domingo, P., Holmes, R. Menocal, A. R. \& Jones, N.(2013).

Assessment of the Evidence of Dwyer, L. \& Guaim, R.C. (2012). Gender and Conflict in Mindanao. New York: The Asia Foundation 21-22. 
10. European Parliament. Retrieved from: https://www.europarl.europa.eu/portal/en.

11. Fox, M.J. (2004). Girl Soldiers: Human Security and Gendered Insecurity. Security Dialogue 35/4 pp.465-79.

12. Global Study on the Implementation of United Nations Security Council Resolution 1325 | UN Women (2021). Retrieved from https://wps.unwomen.org/ ( last access 25/4/2021).

13. Jacqueline H.R.\& Demeritt, A.(2014). Female Participation and Civil War Relapse. Civil Wars, Vol. 16, No. 3, 346-368.

14. Karuru, L.N. (2001). Factors influencing women's political participation in Kibera division, Nairobi Master of ARTS in Anthropology: University of Nairobi Institute Of Anthropology, Gender And African Studies. Retrieved from:

http://erepository.uonbi.ac.ke:8080/xmlui/handle/123456789/20845. (Last access 01/04/21).

15. Klein, R.S. (2012, January). The Role of Women in Mediation and Conflict Resolution: Lessons for UN Security Council Resolution 1325. Washington and Lee Journal of Civil Rights and Social Justice, Vol 18,Issue 2, p 277-313.

16. Links between Gender Equality, Peace Building and State Building. London: Overseas Development Institute (ODI), P 23.

17. Lonsway, K. (2002). Men, Women and Police Excessive Force: A Tale of Two Genders: A Content Analysis of Civil Liability Cases, Sustained Allegations and Citizen Complaints. Los Angeles: National Center for Women and Policing.

18. Mason, S. (2009). Insider Mediators. Retrieved from https://berghoffoundation.org/library/insider-mediators-exploring-their-key-role-ininformal-peace-processes (last access 01/06/21).

19. O’reilly, M., Ó Súilleabháin, A. \& Paffenholz, T. (2015). Reimagining Peace Making: Women's Roles in Peace Processes. New York, International Peace Institute, $\mathrm{P} 6$

20. O'reilly, M. (2020). Why Women? Inclusive Security and Peaceful Societies . Inclusive Security October 2015 Report. Retrieved from: https://www.inclusivesecurity.org/wp-content/uploads/2020/02/WhyWomen-Brief-2020.pdf . (last access in 2/5/2021).

21. Page, M., Whitman, T. \& Anderson, C. (2009). Strategies for Policymakers: Bringing Women into Negotiations._Washington, DC: The Institute for Inclusive Security, $\mathrm{p} 16$.

22. Porter, E. (2008). Peace Building, Women in International Perspective. London: Routledge, p 37. 
23. Potter M. (2008) Women, Civil Society and Peace-Building in Northern Ireland: Paths to Peace through Women's Empowerment. In: Farrington C. (eds) Global Change, Civil Society and the Northern Ireland Peace Process. New Security Challenges Series. Palgrave Macmillan, London. https://doi.org/10.1057/9780230582552 7. (Last access 26/5/2021)

24. Porter, E. (2008). Peace Building, Women in International Perspective. London: Routledge: $\mathrm{p} 37$

25. Promoting Women's Participation in Peace Negotiations and Peace Processes (2014). Federal Ministry for Economic Cooperation and Development. GIZ. Retrieved from: https://eeas.europa.eu/archives/features/features-workingwomen/working-with-women/docs/2014-05-08 toolkit_promotingwomens-participation-peace-neg en.pdf (last access 20/5/2021).

26. Sultana, A. (2012). Patriarchy and Women's Subordination: A Theoretical Analysis. Arts Faculty Journal, 4, 1-18. Retrieved from: https://doi.org/10.3329/afj.v4i0.12929.

27. United Nations (2021). Coronavirus | United Nations. [online] United Nations. Retrieved from:

https://www.un.org/en/coronavirus. (Last access: 25/4/2021).

28. United Nations Organization.

https://www.un.org/millenniumgoals/gender.shtml (Last access 30/4/2021).

29. UN Women's Work on Economic Empowerment-Policy Brief. UN Women. Retrieved from:

http://www.unwomen.org/. (last access: 27/05/21).

30. Urban Institute. Retrieved from: https://www.urban.org/urban-wire/sixways-enable-womens-economic-empowerment. (Last accessed 27/5/2021)

31. Welby, S. (1997). Theorizing Patriarchy, Oxford: Blackwell, p 48.

32. Women's Economic Empowerment is a Pre-requisite for Inclusive and Equitable Economic Growth. Women Deliver. Retrieved from: https://womendeliver.org/investment/boost-womens-economicempowerment/. Last accessed 31/05/2021)

33. York, J. (1998)." The Truth about Women and Peace", in Lois Ann Lorentzen and Jennifer Turpin (eds), The Women and War Reader. London: New York University Press P24.

34. Zelizer, C. (2013). Integrated Peace Building: Innovative Approaches to Transforming Conflict Boulder: Westview Press, P 113. 